\title{
PENINGKATAN MUTU PENDIDIKAN KARAKTER MELALUI PERAN ORANG TUA DALAM KELUARGA
}

\author{
Oleh \\ Ni Komang Sutriyanti \\ Dosen pada Fakultas Dharma Acarya IHDN Denpasar
}

\begin{abstract}
Characters are vital aspects for the national human resources as their quality will determine the progress of the nation. The families are the main and elementary places for the character education. The good and bad relationship between husband and wife, parents and children, between children contributes to the success of the family education. It creates the interactional situation for the education. Implanting the character values is one of the ways to improve the character education to realize the quality human resources.
\end{abstract}

Key words: character education, parents, family

\section{PENDAHULUAN}

Pembangunan karakter bangsa merupakan sebuah kebutuhan asasi dalam proses berbangsa karena hanya bangsa yang memiliki karakter dan jati diri kuat akan eksis. Secara ideologis, pembangunan karakter merupakan upaya mengejawantahkan ideologi Pancasila dan kehidupan berbangsa dan bernegara. Secara normatif, pembangunan karakter bangsa merupakan wujud nyata langkah mencapai tujuan negara. Secara historis, pembangunan karakter bangsa merupakan sebuah dinamika inti proses kebangsaan yang terjadi tanpa henti dalam kurun sejarah, baik pada zaman penjajah, maupun pada zaman kemerdekaan. Secara sosiokultural, pembangunan karakter bangsa merupakan suatu keharusan dari suatu bangsa yang multikultur.

Karakter bangsa merupakan aspek penting dari kualitas sumber daya manusia karena kualitas karakter bangsa menentukan kemajuan suatu bangsa. Karakter yang berkualitas perlu dibentuk dan dibina sejak usia dini, bahkan semasih dalam kandungan. Menurut Freud (dalam Muslich, 2011:35) menyatakan bahwa kegagalan penanaman kepribadian yang baik di usia dini dapat membentuk pribadi yang bermasalah di masa dewasanya kelak. Pembentukan karakter pada anak di usia dini menjadi sebuah hal yang problematik.

Salah satu lembaga pendidikan tertua mengemban tugas dan tanggung jawab dalam mencapai tujuan pendidikan adalah keluarga. Oleh sebab itu, keluarga seharusnya mampu menciptakan situasi dan kondisi yang baik sehingga mampu menghasilkan generasi yang berkualitas (suputra). Apabila anak tidak mendapatkan pendidikan yang baik di keluarga, maka secara tidak langsung pendidikan akan mencetak anak yang tidak baik (kuputra). Ki Hajar Dewantara (dalam Shochib, 1998: 10) menjelaskan bahwa keluarga merupakan pusat pendidikan yang pertama dan terpenting karena sejak timbulnya adab kemanusiaan sampai saat ini, keluarga selalu memengaruhi pertumbuhan budi pekerti 
tiap-tiap manusia. Disamping itu, orang tua dapat menanamkan benih kebatinan yang sesuai dengan kebatinannya sendiri ke dalam jiwa anak. Inilah hak orang tua yang utama dan tidak bisa dibatalkan oleh orang lain.

Keluarga merupakan jalur pendidikan pertama dan utama bagi anak merupakan tempat pertama kalinya anak-anak memperoleh pendidikan dan pengajaran dari orang tua. Mulai dari belajar bercakap-cakap, mengenal nama anggota badan, anggota keluarga, mengenal warna, penanaman disiplin tentang makan, tidur dan sebagainya. Keluarga juga memiliki tempat dan fungsi yang sangat unik, dinamis, memiliki peran sosial, pendidikan sekaligus peran keagamaan. Seorang anak sebelum mengenal masyarakat yang lebih luas dan mendapat bimbingan dari sekolah, lebih awal memperoleh bimbingan dari keluarga. Seorang anak pertama kalinya mendapatkan penanaman dan pembentukan karekter dari kedua orang tua. Demikian pula dalam keseluruhannya kehidupan anak lebih banyak dihabiskan dalam lingkungan keluarga.

Lickona (2012: 81) menegaskan keluarga sebagai pendidik karakter yang paling utama. Keluarga adalah pihak pertama yang paling penting dalam memengaruhi karakter anak. Tugas sekolah adalah memperkuat nilai karakter positif (etos kerja, rasa hormat, tanggung jawab, jujur, dan lain-lain) yang diajarkan di rumah. Kenyataannya, tentu saja ini sering terjadi sebaliknya. Banyak orang tua yang tidak memenuhi aturan peran penting sebagai pendidik dalam membentuk karakter anak. Seharusnya keluarga meletakkan fondasi sebagai dasar, dan sekolah membangun di atas fondasi itu. Penjelasan tersebut di atas, telah menginspirasi penulis untuk membahas tentang "Peningkatan Mutu Pendidikan Karakter Melalui Peran Orang Tua dalam Keluarga".
II. PEMBAHASAN

2.1 Teori Sistem dan Teori Perkembangan Moral dalam Pendidikan Karakter di Lingkungan Keluarga

\section{1) Teori Sistem}

Menurut Refagen (dalam Tampubolon, 2004: 2) A Sistem is a set of objects together with relationships between the objects and between their attributes. Berdasarkan definisi tersebut dapat dikatakan bahwa suatu sistem adalah merupakan kumpulan dari objek-objek bersama-sama dengan hubungannya, antara objek-objek dan antara atribut mereka yang dihubungkan dengan satu sama lain dan kepada lingkungannya sehingga membentuk suatu kesatuan yang menyeluruh (whole).

Dua objek yang menjadi fokus utama Teori Sistem adalah kompleksitas (complexity) dan saling berhubungan (interdependence) (Winardi, 1980: 129). Teori sistem pertama kali dicetuskan oleh Minuchin (1974), yang mengajukan skema konsep yang memandang keluarga sebagai sebuah sistem yang bekerja dalam konteks sosial dan memiliki tiga komponen. Pertama, struktur keluarga berupa sistem sosiokultural yang terbuka dan transformasi. Kedua, keluarga senantiasa berkembang melalui sejumlah tahap yang mensyaratkan penstrukturan. Ketiga, keluarga beradaptasi dengan perubahan situasi kondisi dalam usahanya untuk mempertahankan kontinuitas dan meningkatkan pertumbuhan psikososial tiap anggotanya.

Menurut teori sistem, keluarga dianggap sebagai sebuah sistem yang memiliki bagianbagian yang berhubungan dan saling berkaitan. Keluarga sebagai sistem harus dipandang sebagai keseluruhan, mempunyai struktur penopang, tujuan, menjaga keseimbangan, mempunyai kelembaman, batas-batas, subsistem, dan mengikuti prinsip equifinalty dan 
equipotentiality. Pendekatan teori sistem memandang keluarga sebagai kelompok yang memiliki hierarki, yang artinya bahwa terdapat subsistem-subsistem yang membuat kualitas keluarga ditentukan oleh kombinasi dari kualitas individu atau relasi dua pihak (Lestari, 2012: 30). Disamping itu juga kehidupan keluarga dipengaruhi oleh berbagai sistem yang melingkupinya, yakni microsistem, mesosistem, macrosistem, dan choronosistem.

Dattilio (dalam Geldard, 2011) menyatakan bahwa teori sistem memandang sebuah keluarga sebagai suatu sistem yang meliputi individu di dalam keluarga dan cara para individu ini berfungsi bersama. Lebih lanjut, sistem dalam keluarga terdiri dari bagianbagian yang lebih kecil dan disebut subsistem. Secara khusus, subsistem-subsistem dalam keluarga terdiri dari orang tua, perpasangan keduanya, dan saudara kandung. Dalam setiap keluarga, bisa jadi ada subsistem-subsistem lain dalam kaitannya dengan faktor gender, ikatan emosional, aliansi dan koalisi. Selain itu, keluarga dalam posisi yang lebih luas dapat dipandang sebagai suatu subsistem bagi sistem yang lebih luas lagi. Teori sistem ini menyatakan bahwa keluarga sebagai sebuah sistem yang bekerja dalam konteks sosial serta beradaptasi dengan perubahan situasi kondisi dalam usahanya untuk mempertahankan kontinuitas dan meningkatkan pertumbuhan psikososial tiap anggotanya.

\section{2) Teori Perkembangan Moral}

Perkembangan anak berkaitan erat dengan perkembangan jiwa dan agamanya. Sehingga jika orang tua atau pendidik ingin berhasil dalam tugasnya mendidik anak-anak yang dipercayakan kepadanya, maka harus memahami perkembangan jiwa anak yang dihadapinya, disamping kemampuan ilmiah yang dimilikinya, serta penguasaan terhadap metode dan keterampilan mendidik. Pengertian akan ciri-ciri perkembangan jiwa anak pada usia tertentu, akan membantu dalam materi pendidikan yang cocok dengan usia anak, serta akan membantu pula dalam penggunaan metode yang sesuai, sehingga pesan pendidikan dapat diterima dengan penuh minat dan respon anak (Munasir, 2011: 61). Berdasarkan paparan di atas, dalam hal ini penulis menggunakan teori perkembangan moral anak menurut beberapa ahli yaitu.

\section{a. Teori Kognitif Piaget}

Teori Piaget menyatakan bahwa dua proses yang mendasari perkembangan anak antara lain organisasi dan adaptasi. Untuk memahami dunia, kita mengorganisasikan pengalaman-pengalaman kita. Dengan menggorganisasikan pengamatan dan pengalaman kemudian kita menyesuaikan (adaptasi) pemikiran kita dengan ide-ide baru. Piaget percaya bahwa manusia beradaptasi dalam dua cara yakni asimilasi dan akomodasi. Asimilasi terjadi saat anak menggabungkan informasi ke dalam pengetahuan yang telah mereka miliki. Akomodasi terjadi bila anak menyesuaikan pengetahuan mereka agar cocok dengan informasi dan pengalaman baru. Tahaptahap perkembangan kognitif Piaget antara lain: (1) tahap sensorimotor (dari lahir-2 tahun), pada tahap ini anak membangun pemahaman mengenai dunia dengan mengkoordinasikan pengalaman sensoris (seperti melihat dan mendengar), (2) tahap praoperasional (antara usia 2 tahun sampai 7 tahun), pada tahap ini anak mulai menjelaskan dunia dengan katakata, gambar, dan lukisan, (3) tahap operasional konkret (sekitar 7 sampai 11 tahun), pada tahap ini anak dapat melakukan penalaran logis menggantikan pikiran intuitif selama penalaran dapat diterapkan pada contoh kasus dan konkret, dan (4) tahap operasional formal (usia 11 sampai 15 tahun), pada tahap ini anak melampaui pengalaman yang konkret dan berfikir dalam istilah yang abstrak dan logis. Sebagai bagian dari berfikir, remaja menciptakan bayangan situasi ideal. Mereka dapat berfikir mengenai bagaimana orang tua 
seharusnya dan membandingkan orang tua dengan standar ideal ini.

\section{b. Teori Kognitif Sosial-Budaya}

Teori Vygotsky merupakan teori kognitif yang mengutamakan bagaimana interaksi sosial dan budaya menuntun perkembangan kognitif. Vigotsky menggambarkan perkembangan anak sebagai sesuatu yang tidak terpisahkan dari aktivitas sosial dan budaya. Pengetahuan tidak dihasilkan dari dalam individu melainkan dibangun melalui interaksi dengan orang lain dan benda budaya seperti buku. Hal ini menunjukkan bahwa pemahaman dapat ditingkatkan melalui interaksi dengan orang lain dalam aktivitas dan kooperatif. Interaksi sosial anak dengan orang dewasa yang lebih terampil serta teman sebaya adalah penting dalam meningkatkan perkembangan kognitif (Mirawati, 2011: 62).

\subsection{Etika Dalam Keluarga}

\section{1) Etika Suami dan Istri}

Hubungan pernikahan sebagai hubungan yang dilakukan atas dasar cinta kasih, atas dasar saling menyukai dan direstui oleh para orang tua kedua belah pihak. Lebih penting bahwa pernikahan itu dilakukan dengan perjanjian yang melibatkan nama Tuhan Yang Maha Agung, menjadikan-Nya sebagai saksi dan juga disaksikan oleh semua manusia yang hadir. Oleh karena itulah perjanjian dalam pernikahan merupakan perjanjian yang teramat sakral dan bukan sandiwara atau main-main.

Pada dasarnya yang menjadi kewajiban suami tidaklah hanya menjadi hak bagi istri, tetapi juga menjadi kewajiban istrinya. Sebaliknya, yang menjadi kewajiban istri, tidaklah hanya menjadi hak suaminya, tetapi juga sckaligus sebagai kewajiban suami. Dengan kata lain, hak dan kewajiban suami adalah juga menjadi hak dan kewajiban istri. Hanya peran yang bersifat fitrah yang tidak bisa ditukar atau digantikan oleh pasangannya, seperti mengandung atau hamil, haid atau menyusukan anak yang menjadi kewajiban istri yang tentunya tidak bisa digantikan perannya oleh suami.

Selain itu, yang juga penting adalah adanya komunikasi yang baik antara suami dan istri. Sekarang ini dengan alasan untuk memperbaiki tingkat ekonomi keluarga, banyak pasangan suami-istri, memilih untuk bekerja mencari nafkah. Kesibukan yang terus meningkat membuat pasangan suami-istri sering lupa akan pentingnya komunikasi tatap muka untuk menjaga hubungan pernikahan tetap harmonis. Minimnya komunikasi seperti itu rentan memunculkan permasalahan dalam hubungan suami istri. Jika dibiarkan, bisa jadi pasangan itu akhirnya harus bercerai (Kurniawan, 2013: 67-68).

Baik buruknya hubungan atau interaksi antara suami dan istri atau ayah dan ibu sangat menentukan kesuksesan pendidikan karakter di lingkungan keluarga, terutama dalam menciptakan situasi dan interaksi edukatif. Situasi edukatif adalah terciptanya suasana atau keadaan yang memungkinkan terjadinya proses tindakan yang mengarah pada proses pendidikan. Sementara interaksi edukatif adalah interaksi yang mengandung nilai-nilai pendidikan. Situasi dan interaksi ini tidaklah muncul dengan sendirinya, tetapi harus diciptakan, diusahakan bahkan direkayasa oleh suami-istri atau ayah-ibu, dan orang-orang dewasa lain yang bertanggung jawab dalam pelaksanaan pendidikan karakter di lingkungan keluarga.

\section{2) Etika Orang Tua dengan Anak}

Setiap orang tua atau pasangan suami-istri atau ayah-ibu senantiasa mengharapkan kehadiran anak sebagai bukti dari buah cinta kasih mereka. Namun hubungan antara orang tua dan anak bukanlah hubungan kepemilikan, melainkan hubungan pemeliharaan. Hubungan atau interaksi antara orang tua dengan anak selalu ditandai dengan perkataan dan perbuatan. Namun, tidak sedikit dari perilaku 
atau perangai orang tua justru membuat anak tertekan atau stres bahkan depresi.

Dalam kekawin Niti Sastra VIII.3 disebutkan ada lima kriteria yang menjadi kewajiban orang tua yang disebut Panca Vida yang terdiri dari Sang Ametwaken (melahirkan), Sang Nitya Maweh Binojana (orang tua mempunyai kewajiban untuk memberikan makan dan minum), Sang Manggupadyaya (orang tua berkewajiban untuk mengupayakan pendidikan bagi anakanaknya), Sang Anyangaskara (kewajiban orang tua menyucikan pribadi anak secara utuh lahir dan bathin), dan Matulung Urip Rikalaning Baya (kewajiban orang tua untuk menolong si anak di saat mendapat suatu bencana atau kesusahan) (Swastika, 2007: 1618).

Anak merupakan dambaan bagi setiap keluarga. Tidak ada orang yang telah bersuami istri tidak menginginkan anak. Anak adalah generasi peners bagi kelangsungan keluarganya. Di dalam Slokantara disebutkan sebagai berikut.

Kalinganya, dening anibâkna warahwarah ring anak, yan limang tahun tuwuhnya, kadi dening angering anak sang prabhu dening anibâken warah iriya. Matuha pwa ya ikang swaputra, kateka ring sadacea tahun tuwuhnya, irika ta yan warah hulun dening anibâken warah-warah iriya, Kunang yan atuha ikang anak, kateka ring nembelas tahun tuwuhnya, ika ta yan kadi dening amarah-marah ing mitra dening anibâken warah-warah iriya, mangkana karma ning marah-marah putra, ling Sang Hyang Aji.

(Slokantara, 22)

Terjemahannya:

Perlakuan orang tua terhadap anakanaknya ialah sebagai berikut: selama lima tahun dari bayi ia harus diperlakukan sebagai raja. Ketika sampai anak itu bertambah umur sepuluh tahun lagi ia harus dilatih sebagai pelayan. Dan jika setelah anak itu berumur enam belas ia harus diperlakukan sebagai kawan terhadap kawan. Inilah cara mendidik anak. Demikian ketentuan dalam kitab suci (Sudharta, 2003: 83-84).

Kutipan tersebut di atas memberikan cara mendidik anak bagi para orang tua dengan selalu memperhatikan perkembangan anaknya yang berdasarkan pada umur dari anak bersangkutan. Saat ini model seperti ini mungkin juga telah dilupakan oleh para orang tua, karena orang tua sekarang telah menyerahkan anaknya $100 \%$ di sekolah, sehingga sentuhan pendidikan karakter yang mestinya dapat diberikan di tingkat rumah tangga menjadi kabur. Anak sekarang hanya dijejali dengan pengetahuanpengetahuan yang hanya mengutamakan kepintaran saja.

\section{3) Etika Anak dengan Orang Tua}

Menciptakan keluarga yang damai, rukun, dan bahagia diperlukan adanya kerjasama yang harmonis diantara semua anggota keluarga. Saling pengertian dan saling menghormati menjadi suatu keharusan dalam sebuah keluarga. Tidak akan mungkin tercipta keluarga yang sejahtera apabila diantara anggota keluarga tidak adanyahidup saling menghormati tugas dan kewajiban seperti yang telah disebutkan seperti di atas itu. Untuk ini perlu juga dikutipkan salah satu isi dari pustaka suci Weda seperti berikut.

sam gacchadhvam sam vadadhvam sam vo manamsi janatam dewa bhagam yatha purve sanjanana upasate

(Rgveda, X. 191.2)

Terjemahannya:

Wahai umat manusia anda seharusnya berjalan bersama-sama dengan pikiran yang sama seperti halnya para pendahulumu bersama- sama membagi tugas mereka, begitulah anda mestinya memakai hakmu (Titib, 1998: 348). 
Kutipan tersebut di atas sebagai motivasi untuk sebuah keluarga yang mendambakan keluarga yang sejahtera secara lahir dan batin. Perlu adanya kesamaan-kesamaan sehingga apa yang dicita-citakan dapat terwujud secara sempurna dan juga Bangsa dan Negara juga mendapat dampaknya sehingga kesejahteraan secara umum juga akan terwujud dengan baik.

\section{4) Etika Anak dengan Anak}

Interaksi antar-anak adalah hubungan timbal balik antar-anak yang belum dewasa dalam keluarga pada satu rumah. Interaksi atau hubungan timbal balik antar anak-anak yang belum dewasa dalam keluarga pada satu rumah. Interaksi antar anak tersebut dapat berupa hubungan timbal balik antara adikkakak, atau antara anak yang berbeda jenis kelamin (anak laki-laki dan anak perempuan).

Salim (dalam Kurniawan, 2013: 75) menyatakan bahwa, pola interaksi antar-anak di rumah dapat dibedakan menjadi dua bentuk. Pertama, interaksi antar-anak yang berbeda usia (yang muda dengan yang tua), yaitu hubungan timbal balik antara adik dan kakak. Interaksi itu harus menunjukkan situasi dan interaksi edukatif. Pihak yang muda harus menunjukkan sikap hormatnya kepada yang lebih tua dan yang lebih tua menunjukkan kasih sayang, mengayomi dan melindungi yang lebih muda. Kualitas interaksi antar--anak tersebut dapat diamati dalam tutur kata, sikap, dan tindakan keseharian selama mereka berada dan bergaul di rumah.

Kedua, interaksi antaranak yang berbeda jenis kelamin, yaitu hubungan timbal balik antara anak laki-laki dan anak perempuan yang berada dalam satu rumah. Dalam pergaulannya anak laki-laki dan perempuan dapat saling memengaruhi. Jika salah satunya lebih mendominasi dan salah satunya memiliki kecenderungan mengikuti yang lainnya, dapat memengaruhi sifat dan sikap kesehariannya. Kemudian pada gilirannya dapat memengaruhi pertumbuhan dan perkembangan kejiwaannya, terutamajika interaksi keduanya tidak terawasi secara baik oleh orang tua atau orang dewasa lain yang ada di rumah. Sebagai contoh, anak laki-laki yang cenderung mengikuti anak perempuan, mulai cara berpakaian, permainan sampai pada cara bertutur kata atau berperilaku maka kecenderungan anak laki-laki tersebut akan bergaya seperti perempuan. Sebaliknya, jika anak yang perempuan yang lebih cenderung mengikuti gaya anak laki-laki, anak perempuan tersebut akan memiliki kecenderungan menjadi tomboy (bersifat dan berpenampilan seperti laki-laki). Di samping itu, karena perbedaan jenis kelamin juga berarti berbeda baik fisik dan sifat maka perlu ada batas-batas tertentu yang boleh dan tidak boleh dilakukan selama mereka melakukan interaksi. Jika salah seorang dari anak tersebut sudah berusia sepuluh tahun, sebaiknya segera dipisahkan tempat tidurnya bahkan akan lebih baik sebelum mencapai usia tersebut.

\subsection{Nilai-Nilai Karakter yang Ditanamkan Orang Tua dalam Keluarga \\ 1) Nilai Religius}

Religius merupakan sikap dan perilaku yang menunjukkan keyakinan akan adanya kekuatan sang pencipta atau Tuhan Yang Maha Esa. Keyakinan ini disertai kepatuhan dan ketaatan dalam mengikuti perintah dan menjauhi segala larangan-Nya. Ini diwujudkan dengan taat beribadah dan berperilaku yang sesuai dengan apa yang telah diatur oleh agama dan tidak melakukan apa yang dilarang oleh agama (Titib, 2006: 67). Sikap dan perilaku yang patuh dalam melaksanakan ajaran agama yang dianutnya, toleran terhadap pelaksanaan ibadah agama lain, dan hidup rukun dengan pemeluk agama lain (Balitbangpuskur, 2010: 37). Adapun religiusitas merupakan orang yang menganggap beragama sebagai sesuatu yang "penting" lebih dikenal sebagai orang yang bekerja untuk mereka yang memerlukan pertolongan, ikut serta berkampanye untuk keadilan sosial, dan menyisihkan uang untuk 
memberikan pertolongan, terutama dalam jangka waktu yang panjang (Suhardi, 2014: 189).

Mengenai nilai religius anak, sesuai dengan yang dinyatakan oleh Stark dan Glock (dalam Suhardi, 2014: 3) menyebutkan ada lima unsur yang dapat mengembangkan manusia menjadi religius. Yaitu, keyakinan agama, ibadat, pengetahuan agama, pengalaman agama, dan konsekuensi dari keempat unsur tersebut. Keyakinan agama adalah kepercayaan atas doktrin ketuhanan, seperti percaya terhadap adanya Tuhan, akhirat, surga, neraka, takdir dan lain-lain. Ibadat adalah cara melakukan penyembahan kepada Tuhan dengan segala rangkaiannya. Pengetahuan agama adalah pengetahuan tentang ajaran agama meliputi berbagai segi dalam suatu agama. Pengalaman agama adalah perasaan yang dialami orang beragama, seperti rasa tenang, tenteram, bahagia, syukur, patuh, taat, takut, menyesal, bertobat dan lainnya. Terakhir konsekuensi dari keempat unsur tersebut adalah aktualisasi dari doktrin agama yang dihayati oleh seseorang yang berupa sikap, ucapan, dan perilaku atau tindakan.

Nilai religius pada anak tidak cukup diberikan melalui pelajaran, pengertian, penjelasan, dan pemahaman. Kemudian, membiarkan anak berjalan sendiri. Penanaman nilai religius pada anak memerlukan bimbingan, yaitu usaha untuk menuntun, mengarahkan sekaligus mendampingi anak dalam hal-hal tertentu, terutama ketika anak merasakan ketidakberdayaannya atau ketika anak sedang mengalami suatu masalah yang dirasakannya berat. Maka, kehadiran orang tua dalam membimbingnya akan sangat berarti dan berkesan bagi anak-anaknya. Keteladanan orang tua juga merupakan hal penting dalam penanaman nilai religius pada anak. Anak cenderung mengidentifikasikan dirinya dengan orang tua, baik pada ibu ataupun pada ayahnya. Segala ucapan, gerak-gerik atau tingkah laku keseharian orang tua akan diperhatikan oleh anak dan cenderung akan diikuti, paling tidak akan dikritisi oleh anaknya. Orang tua yang selalu berbicara dan berperilaku santun akan lebih mudah mengingatkan anaknya untuk bicara dan berperilaku santun. Demikian pula orang tua yang suka berderma di hadapan anaknya akan menjadi pelajaran dan pengalaman baik bagi anaknya. Kebiasaankebiasaan baik orang tua yang mencerminkan pengamalan nilai-nilai religius ini akan menjadi contoh bagi anak-anaknya, yang suatu saat akan muncul dalam perilaku keseharian anakanaknya (Kurniawan, 2013: 85).

Nilai religius merupakan nilai pembentuk karakter yang sangat penting. Manusia berkarakter adalah manusia yang religius. Religius adalah penghayatan dan implementasi ajaran agama dalam kehidupan sehari-hari (Naim, 2012: 124). Sikap religius merupakan cerminan orang beriman yang memiliki keyakinan yang mantap terhadap Tuhan Yang Maha Esa. Dalam kitab Rgveda IX.64.21 dijelaskan:

abhi venâ anûsateyaksanti pracetasah, mjjanty-avicetasah.

Terjemahannya:

Orang yang beriman kepada Tuhan Yang Maha Esa yang terpelajar mempersembahkan doa-doa dan para ahli keagamaan yang dicerahkan berniat menghaturkan yajña. Orang yang tidak beriman kepada Tuhan Yang Maha Esa, dan orang yang bodoh akan tenggelam (Titib, 2006: 67).

Sloka tersebut di atas menegaskan bahwa orang yang beriman kepada Tuhan Yang Maha Esa, orang yang terpelajar selalu mempersembahkan doa-doa pujian. Orang yang tidak beriman kepada Tuhan Yang Maha Esa serta orang yang bodoh akan tenggelam ke jurang penderitaan. Oleh karena itu, menjadi manusia harus selalu mempertebal sradha dan bhakti kepada Tuhan Yang Maha Esa karena manusia tidak ada apa-apanya dihadapan Tuhan. 


\section{2) Nilai Mandiri}

Mandiri adalah sikap dan perilaku yang tidak mudah tergantung pada orang lain dalam menyelesaikan tugas-tugas. Dalam keluarga, kemandirian (self-relience) adalah salah satu nilai karakter yang harus dibentuk oleh orang tua dalam kehidupan sehari-hari.

Mustari (2014: 78) menyatakan bahwa orang mandiri adalah orang yang cukup-diri (self-sufficient), yaitu orang yang mampu berpikir dan berfungsi secara independen, tidak perlu bantuan orang lain, tidak menolak risiko dan bisa memecahkan masalah, bukan hanya khawatir tentang masalah-masalah yang dihadapinya. Orang seperti ini akan percaya pada keputusannya sendiri, jarang membutuhkan orang lain untuk meminta pendapat atau bimbingan orang lain. Orang yang mandiri dapat menguasai kehidupannya sendiri dan menangani apa saja dari kehidupan ini yang ia hadapi.

Kemandirian merupakan salah satu modal penting bagi anak-anak untuk bertahan hidup kelak saat mereka dewasa. Karenanya mengajarkan kemandirian merupakan salah satu tanggung jawab terpenting yang dimiliki orang tua. Berikut beberapa hal yang dapat dilakukan orang tua untuk mulai menanamkan kemandirian pada anak-anak.

Nilai kehormatan dan harga diri yang terdapat dalam kemandirian tidak bisa dinilai dengan sesuatu apa pun. Sebab, apabila harga diri dan kehormatan seseorang tidak ada maka habislah ia. Menumbuhkan kemandirian dalam diri anak didik bisa dilakukan dengan melatih bekerja dan menghargai waktu. Misalnya, anak didik dilatih untuk berwirausaha dari hal-hal kecil, seperti menjual kerupuk, es batu, dan lain sebagainya. Atau, anak didik diberi tanggung jawab mencari makan untuk kambing sekali atau dua kali dalam seminggu. Selain itu, anak dilatih untuk mena-bung sebagai investasi jangka panjang, tidak menghabiskan uang seketika tanpa berpikir masa depan. Mem-bangun kemandirian berarti menanamkan visi dalam diri anak. Dalam kemandirian inilah, terdapat nilainilai agung yang menjadi pangkal kesuksesan seseorang, seperti kegigihan dalam berproses, semangat tinggi, pantang menyerah, kreatif, inovatif, dan produktif, serta keberanian dalam menghadapi tantangan, optimis, dan mampu memecahkan masalah yang dihadapi (Asmani, 2012: 92-93).

\section{3) Nilai Kerja Keras}

Kerja keras merupakan perilaku yang menunjukkan upaya sungguh-sungguh dalam mengatasi berbagai hambatan belajar dan tugas, serta menyelesaikan tugas dengan sebaikbaiknya (Balitbangpuskur, 2010:9). Sikap dan perilaku yang suka berbuat hal-hal yang positif dan tidak suka berpangku tangan serta selalu gigih dan sungguh-sungguh dalam melakukan sesuatu. Ini diwujudkan dengan perilaku yang selalu menggebu-gebu dalam melakukan sesuatu dan tidak kenal lelah sampai akhir pekerjaan (Titib, 2006: 59).

Penanaman kerja keras dapat dilakukan dengan mengajarkan hal yang baik, memerhatikan supaya segala usahanya dapat berbuah lezat dan dapat dirasakan manfaatnya, baik usaha itu tertuju pada bidang pelajaran ataupun pekerjaan. Kepentingannya agar apaapa yang diusahakan itu tidak mudah roboh dan hancur, tidak mudah rusak dan punah, dihindarkan dari rasa mempermudah pekerjaan, sehingga menyebabkan mudah binasa dan terbengkalai (Suhardi, 2014: 44).

Tidak ada keberhasilan yang bisa dicapai tanpa kerja keras. Kerja keras melambangkan kegigihan dan keseriusan mewujudkan cita-cita. Sebab, hidup yang dijalani dengan kerja keras akan memberikan nikmat yang semakin besar manakala mencapai kesuksesan. Dalam dunia pendidikan pelajar yang sukses adalah yang menjalani proses pembelajaran secara serius dan penuh dengan kerja keras. Sangat jarang ada peserta didik yang bisa sukses tanpa belajar (Naim, 2012: 148-149). dalam Niti Sataka disebutkan: 
Sthalyam vaiduryammayyam pacati ca lasunam candanairindhna naddyaih saovarnairlangalagrairvilikhati vasudhamarkatulasya hetoh

chittva karpurakhandan vrttiriha kurute kodravanam samantat prapyemam karmabhumin carati na manujo yastapo mandabhagyah.

(Niti Sataka. 96)

Terjemahannya:

Seseorang yang telah dilahirkan ke dunia, apabila tidak bekerja keras di dunia yang merupakan lapangan lapangan karma, maka ia adalah orang bodoh. Ia membakar dirinya dengan nafas yang ibaratkan kayu, memasak bawang putih dalam panic yang terbuat dari mutiara, juga menggemburkan sawah dari kapas dengan bajak emas dan membuat pematang dari kapur untuk melindungi padi (Somvir, 2005: 82).

\section{4). Nilai Toleransi}

Toleransi merupakan kebajikan moral berharga yang dapat mengurangi kebencian, kekerasan, dan kefanatikan. Dengan toleransi, kita juga memperlakukan orang lain secara baik, hormat, dan penuh pengertian. Toleransi tidak melarang kita melakukan penilaian moral, tetapi menuntut kita menghargai perbedaan (Borba, 2008: 225).

Toleransi merupakan sebuah sikap yang memiliki kesetaraan dan tujuan bagi mereka yang memiliki pemikiran, ras, dan keyakinan berbeda-beda. Toleransi adalah sesuatu yang membuat dunia setara dari berbagai bentuk perbedaan (Lickona, 2012: 74). Nilai toleransi merupakan sikap dan tindakan yang menghargai perbedaan agama, suku, etnis, pendapat, sikap, dan tindakan orang lain yang berbeda dari dirinya (Balitbangpuskur, 2010: 10).

Toleransi berarti sikap membiarkan ketidakpekatan dan tidak menolak pendapat, sikap, ataupun gaya hidup yang berbeda dengan pendapat, sikap, dan gaya hidup sendiri. Sikap toleran dalam implementasinya tidak hanya dilakukan terhadap hal-hal yang berkaitan dengan aspek spiritual dan moral yang berbeda, tetapi harus dilakukan terhadap aspek yang luas, termasuk ideologi dan politik yang berbeda (Naim, 2012: 139).

Berkaitan dengan nilai toleransi, orang tua perlu mendidik apa artinya toleransi dan rasa hormat kepada orang lain yang bisa saja menganut pemahaman berbeda darinya. Toleransi adalah kemampuan seseorang untuk menerima perbedaan dari orang lain. Hal ini baru bisa dilakukan oleh seseorang jika ia sudah merasakan dan memahami keterikatan, regulasi diri, afiliasi, dan kesadaran. Ketika ia sudah mampu menjaga hubungan yang sehat dan dekat, merasa berada dalam sebuah kelompok serta merasa nyaman di dalamnya, juga mampu menilai sebuah situasi, melihat kekuatan, kebutuhan, dan ketertarikan orang lain. Rasa hormat merupakan kemampuan untuk melihat serta merasakan nilai di dalam diri kita dan orang lain. Butuh emosi, kognitif, serta kematangan sosial. Membangun rasa menghormati adalah tantangan seumur hidup, namun prosesnya dimulai sejak dini (Kurniawan, 2013: 86).

Berikut adalah beberapa aspek yang perlu diingat oleh orang tua dalam mengajarkan toleransi dan rasa hormat pada orang lain kepada anak.

a) Buat anak merasa bahwa dirinya spesial, aman, dan dicintai. Jangan menghemat kata-kata pujian saat ia memang melakukan hal yang baik dan membanggakan. Anak yang dikasihi akan belajar mengasihi orang lain.

b) Ciptakan sarana belajar di tempat baru, orang-orang baru, dan budaya berbeda. Paparkan pada anak pada banyaknya perbedaan di dunia ini. Ada banyak buku, makanan, event budaya, dan perayaan untuk dikenalkan pada anak. Ajak anak ke acara-acara budaya, kenalkan is akan ritual agama lain. Ajar anak untuk 
berinteraksi dengan orang yang berbeda darinya dengan cara yang sehat. Pahamkan pada anak bahwa tidak ada yang salah dari perbedaan, asal saling menghormati dan toleransi.

c) Gunakan komentar positif untuk membentuk sikap si anak. Hindari penggunaan kata-kata "menuduh", seperti "Jangan begitu, dong!" Coba gunakan kata-kata alternatif yang mendidik, tetapi tidak menyuruh dan membuatnya merasa rendah diri, misal, "Yang lembut ke adik, ya, dia masih kecil, gampang terluka."

d) Tunjukkan caranya. Anak akan belajar untuk bersikap lebih baik, sensitif, dan menghormati orang lain dengan melihat orang tuanya, misalnya dalam berdiskusi, berpikiran terbuka, dan menghargai orang lain (tidak pula menjelek-jelekkan orang lain karena golongannya berbeda dengan Anda).

\section{5). Nilai Kepedulian Sosial}

Kepedulian Sosial merupakan sikap dan tindakan yang selalu ingin memberi bantuan pada orang lain dan masyarakat yang membutuhkannya (Litbangpuskur, 2010: 41). Kemurahan hati, suka menolong, dan dermawan disabdakan oleh Ida Sang Hyang Widhi Wasa untuk dijadikan pedoman oleh umat manusia dalam rangka membimbing jiwa mereka ke arah kesucian. Orang yang dermawan akan memperoleh kemuliaan baik di dunia maupun setelah pulang nanti. Seorang yang dermawan akan selalu memberikan miliknya dengan tulus ikhlas dan penuh kasih sayang kepada orang yang membutuhkan (Supatra, 2005: 9).

Kepedulian adalah empati kepada orang lain yang diwujudkan dalam bentuk memberikan pertolongan sesuai dengan kemampuan. Anak diajari menolong temannya yang sedang dilanda musibah. Misalnya, mengunjungi teman yang sedang sakit, membawakan makanan, mengajari teman tentang materi yang belum dipahami, berbagi ketika sedang makan, dan lain sebagainya. Kepedulian ini sangat penting dalam dalam rangka menumbuhkan rasa persaudaraan dan kekeluargaan, serta menjauhkan diri dari sifat sombong, egois, dan individual. Kepedulian akan menumbuhkan rasa kemanusiaan, kesetiakawanan, dan kebersamaan. Kepedulian yang ditanaman pada masa kecil akan menjadi pondasi kokoh dalam melahirkan kemampuan kolaborasi, sinergi, dan kooperasi (Asmani, 2012: 91).

Kasih sayang merupakan karakter dan keutamaan manusia. Kasih sayang adalah arus bawah yang mendasari nilai-nilai kemanusiaan. Kasih sayang dalam pikiran dalam kebenaran, kasih sayang dalam perasaan adalah kedamaian, kasih sayang dalam pemahaman adalah tanpa kekerasan, kasih sayang dalam tindakan adalah kebajikan (Titib, 2006: 187188).

Untuk menanamkan jiwa sosial tersebut pada anak, orang tua harus lebih banyak melakukan praktik daripada hanya berteori sehingga anak-anak akan mencontoh perbuatan-perbuatan nyata yang orang tuanya lakukan. Banyak hal yang dapat dipraktikkan untuk menanamkan jiwa sosial pada anak, antara lain.
a) Mengajak anak bersama-sama menengok saudara atau tetangga yang sedang sakit;
b) Mengajak anak bersama-sama mengunjungi panti jompo;
c) Rutin bersedekah dan mengajarkan pentingnya bersedekah pada anak;
d) Berbagi kebahagiaan dengan anak- anakjalanan, misalnya saat ulang tahun anak;
e) Menyuguhi minuman pada tukang sampah yang mengangkut sampah dari rumah kita;
f) Berbagi makanan yang kita masak pada tetangga di sekitar yang kurang mampu;


g) Mengajak anak untuk bersama-sama berbagi kebahagiaan di hari raya keagamaan dengan anak-anak di panti asuhan (Kurniawan, 2013: 100).

\section{6). Nilai Disiplin}

Disiplin merupakan suatu tindakan yang menunjukkan perilaku tertib dan patuh pada berbagai ketentuan dan peraturan (Balitbangpuskur, 2010: 9). Disiplin adalah kepatuhan untuk menghormati dan melaksanakan suatu sistem yang mengharuskan orang untuk tunduk kepada keputusan, perintah, dan peraturan yang berlaku. Juga diartikan bahwa disiplin adalah sikap mentaati peraturan dan ketentuan yang telah diterapkan tanpa pamrih (Naim, 2012: 142-143).

Menurut kamus Webste (dalam Ngurah,dkk, 2007: 37) dijelaskan bahwa disiplin mempunyai beberapa pengertian (1) disiplin diartikan kepatuhan terhadap peraturan atau tunduk pada pengawasan, (2) disiplin diartikan latihan yang bertujuan mengembangkan watak agar dapat mengendalikan diri, berperilaku tertib dan efisien, (3) disiplin diartikan sebagai hasil latihan pengendalian diri agar berperilaku tertib.

Disiplin tidak bisa dibangun secara instan dibutuhkan suatu proses panjang agar disiplin menjadi kebiasaan yang melekat kuat dalam diri seorang anak. Oleh karena itu penananaman disiplin harus dilakukan sejak dini. Tujuannya untuk mengarahkan anak agar merasa belajar mengenai hal-hal baik yang merupakan persiapan bagi masa dewasa. Jika sejak dini sudah ditanamkan disiplin, meraka akan menjadikannya sebagai kebiasaan dan bagian dari dirinya (Naim, 2012: 143).

Bernhard (dalam Shochib, 1998: 3) menyatakan bahwa tujuan disiplin diri adalah mengupayakan pengembangan minat anak dan mengem-bangkan anak menjadi manusia yang baik, yang akan menjadi sahabat, tetangga, dan warga negara yang baik. Dalam hal ini terdapat perbedaan yang fundamental antara keluarga di Barat dengan keluarga di Indonesia dalam mengupayakan anak untuk memiliki dasardasar dan mengembangkan disiplin diri. Hal ini karena keluarga di Indonesia dituntut selaras dengan isi yang dikandung oleh undang-undang di atas. Secara tersirat ada tanggung jawab pendidikan yang kodrati dalam memberikan keyakinan beragama yang ditempatkan pada urutan pertama dan menjadi dasar dari substansi lainnya. Oleh sebab itu, tujuan pendidikan yang esensial pada keluarga Indonesia adalah pembinaan, dan pengembangan kepribadian secara utuh dan terintegrasi.

Kurniawan (2013: 87) menyebutkan beberapa hal yang perlu diperhatikan orang tua dalam menanamkan nilai-nilai disiplin pada anaknya yaitu.

a) Orang tua harus konsisten (tidak berubah), yaitu ada kesepakatan antara kedua orang tua (ayah dan ibu) sehingga setiap tindakan dalam menanamkan kedisiplinan tidak berubah-ubah.

b) Berikan aturan yang sederhana dan jelas sehingga anak mudah melakukannya.

c) Jangan menegur anak di hadapan orang lain karena hal itu akan membuat anak merasa malu sehingga tetap mempertahankan tingkah laku tersebut.

d) Alasan dan tata tertib yang dilakukan itu perlu dijelaskan pada anak sehingga anak melakukannya dengan penuh kesadaran.

e) Hadiah berupa pujian, penghargaan, barang/kegiatan (misalnya memperbolehkan bermain, nonton TV, dan lainlain) diberikan apabila anak melakukan perilaku positif. Hal tersebut akan menumbuhkan rasa percaya diri.

f) Orang tua harus berhati-hati dalam memberikan hukuman, jangan sampai menyakiti fisik/jiwa anak. Hukuman 
tidak dapat diberikan terhadap anak di bawah usia tiga tahun, apalagi memukulnya. Hukuman merupakan "pilihan terakhir", lebih baik memuji perbuatannya yang benar daripada menghukum kesalahannya. Demikian pula dalam menghukum anak, sebaiknya hindari emosi yang berlebihan.

g) Jangan terlalu kaku dalam menegakkan disiplin, sesuaikan dengan keadaan situasi anak.

h) Sebaiknya anak dilibatkan dalam setiap membuat tata tertib sehingga anak merasa dihargai dan diakui dalam keluarga.

i) Bersikap tegas bukan berarti bersikap kasar baik dalam tindakan fisik/ perbuatan.

\section{7). Nilai Kejujuran}

Kejujuran merupakan hal yang penting, namun sedikit orang tua yang peduli akan kejujuran anaknya. Kejujuran di saat dewasa tak lepas dari kejujuran yang ditanamkan saat masih anak-anak. Ketika sejak anak-anak sudah ditanamkan kejujuran maka sampai dewasa kejujuran itu akan tertanam dalam jiwa si anak. Beberapa hal yang dapat dilakukan orang tua untuk menumbuhkan kejujuran pada anak, di antaranya sebagai berikut.

a) Jangan membohongi anak. Kadang kala orang tua membohongi anak demi sesuatu hal, misalnya agar anaknya tidak menangis dijanjikan suatu barang, namun ketika anaknya sudah diam barang tersebut tidak diberikan. Dengan demikian, anak akan berpikir ternyata dia dibohongi dan hal itu akan tetap membekas hingga dia dewasa dan ketika dewasa akan berganti membohongi karena sejak kecil telah diajari berbohong oleh orang tuanya.

b) Hargai kejujuran anak. Sedikit sekali orang tua yang mau menghargai kejujuran anaknya sehingga ketika si anak berusaha jujur tidak diberikan ganjaran atas kejujurannya. Jika demikian maka kejujuran dianggap hal yang tidak penting sehingga akan mengabaikan kejujuran tersebut.

c) Tanamkan kejujuran sejak dini. Ketika anak sudah terbiasa jujur sejak kecil maka nilai-nilai kejujuran tersebut akan terpola secara otomatis dalam pribadi anak. Dengan demikian, si anak akan terbiasa jujur hingga di dewasa.

d) Selalu motivasi anak berlaku jujur. Seorang anak memerlukan bimbingan dan motivasi secara bersinergi agar kejujuran yang ditanamkan pada anak tetap berada dalam diri anak (Kurniawan, 2013: 86).

Semua keluarga menyampaikan pesan mo-ral untuk bersikap jujur kepada anakanaknya. Akan tetapi, imple-mentasi dari pesan tersebut dan cara-cara yang digunakan oleh orang tua untuk mengontrol sikap jujur yang dimiliki anak berbeda-beda. Dalam keluarga orang tua bersikap teguh dalam menegakkan sikap jujur pada anak sehingga anak memahami betapa pentingnya bersikap jujur dalam kehidupan. Meskipun bersikap jujur dirasakan sulit, namun orang tua menekankan pesan pada anak bahwa kejujuran akan membawa kebaikan, sedangkan ketidakjujuran akan mengaki-batkan kerugian di kemudian hari (Lestari, 2012: 156).

\section{8). Nilai Kepedulian terhadap Lingkungan}

Kepedulian Terhadap lingkungan merupakan kegiatan yang selalu berupaya mencegah kerusakan lingkungan alam disekitarnya, dan mengembangkan upayaupaya untuk memperbaiki kerusakan alam yang sudah terjadi. Kegiatan yang dilakukan tersebut merupakan wujud bhakti terhadap alam semesta sehingga apabila lingkungan sudah tertata dengan baik maka pancaran dan vibrasi 
alam akan memberikan ketenangan jiwa kepada umat manusia (Balitbangpuskur 2010: 41).

Manusia merupakan makhluk sosial. Ia hidup dan menjadi bagian tidak terpisahkan dari lingkungannya. Karenanya, manusia tidak bisa sepenuhnya egois dan beranggapan kalau dirinya bisa hidup sendiri tanpa peran serta orang lain. Selain tidak logis, sikap egois semacam ini juga membawa implikasi kurang baik bagi tatanan sosial. Kualitas lingkungan hidup sekarang memang cenderung mengalami penurunan. Pencemaran udara, kerusakan hutan, banjir dan persoalan lainnya (Naim, 2012: 200-201).

Sikap kecintaan anak terhadap lingkungan merupakan hasil proses pendidikan yang dialaminya, baik dari sekolah maupun orang tua. Pada umumnya anak menghabiskan dua pertiga hari di rumah. Oleh karena itu, pendidikan yang paling efektif adalah keteladanan dari orang tua. Untuk itu, orang tua perlu membiasakan pola hidup yang bersih, sehat, dan ramah lingkungan dalam keluarga. Tanamkan pula kesadaran, menjaga alam merupakan bagian dari ibadah, yang memberi manfaat bagi peningkatan kualitas hidup. Anak belajar dengan meniru dan mencontoh. Jadi, kalau orang tua melek lingkungan, anak pun akan terpengaruhi.

Kepedulian kepada kelestarian lingkungan perlu dilakukan sejak dini karena pengaruh pada usia dini merupakan dasar pembentukan karakter anak. Mengajarkan cinta lingkungan juga akan menumbuhkan sikap bersyukur. Umumnya, anak yang mencintai alam, cenderung berhati lembut dan juga mengasihi sesama.

Meningkatkan pemahaman anak tentang perlunya menjaga lingkungan, dapat juga dilakukan orang tua dengan berdiskusi mengenai lingkungan bersama anak. Diskusi dapat diarahkan untuk mengetahui penyebab dan perilaku masyarakat yang berakibat pada masalah global lingkungan. Berikan penjelasan sesuai kemampuan pemahaman anak. Sebaiknya gunakan bahasa yang sederhana dan mudah dipahami anak. Dengan begini, anak terbiasa untuk selalu menjaga lingkungannya. Jika kebiasaan baik ini diterapkan sampai mereka besar pasti akan menciptakan karakter yang kuat di dalam diri mereka (Kurniawan, 2013: 98-99).

\section{SIMPULAN}

1. Karakter bangsa merupakan aspek penting dari kualitas SDM karena kualitas karakter bangsa menentukan kemajuan suatu bangsa. Karakter yang berkualitas perlu dibentuk dan dibina sejak usia dini, bahkan semasih dalam kandungan.

2. Keluarga merupakan jalur pendidikan pertama dan utama bagi anak merupakan tempat pertama kalinya anak-anak memperoleh pendidikan dan pengajaran dari orang tua. Keluarga yang rukun dan harmonis akan berpengaruh terhadap karakter anak tersebut.

3. Orang tua ideal sangat dibutuhkan dalam pendidikan karakter di lingkungan keluarga, orang tua dituntut untuk mampu memahami tugas dan kewajibannya.

4. Baik buruknya hubungan atau interaksi antara suami dan istri, orang tua dan anak, serta anak dengan anak sangat menentukan kesuksesan pendidikan karakter di lingkungan keluarga, terutama dalam menciptakan situasi dan interaksi edukatif.

5. Penanaman nilai-nilai karakter dalam keluarga merupakan salah satu upaya peningkatan mutu pendidikan karakter sehingga terwujud sumber daya manusia yang berkualitas.

\section{DAFTAR PUSTAKA}

Agung Oka, I Gusti. 1992. Slokantara. Jakarta: Hanuman Sakti.

Asmani, Jamal Ma'mur. 2012. Buku Panduan Internalisasi Pendidikan Karakter di Sekolah. Jogjakarta: Diva Press.

Balitbangpuskur. 2010. Bahan Ajar Pelatihan Penguatan Metodologi Pembelajaran 
Berdasarkan Nilai-Nilai Budaya Untuk Membentuk Daya Saing dan Karakter Bangsa. Jakarta: Kemendiknas.

Borba, Michele. 2008. Membangun Kecerdasan Moral. Jakarta: PT Gramedia Pustaka Utama.

Geldard David dan Geldard Kathryn. 2011. Konseling Keluarga. Yogyakarta: Pustaka Pelajar.

Kurniawan, Syamsul. 2013. Pendidikan Karakter. Yogyakarta: Ar-Ruzz Media.

Lestari, Sri. 2012. Psikologi Keluarga (Penanaman Nilai dan Penanganan Konflik dalam Keluarga). Jakarta: Kencana Prenada Media Group.

Lickona, Thomas. 2012. Educating For Character( Mendidik Untuk Membentuk Karakter). Jakarta: Bumi Aksara.

2012. Character Matters (Persoalan Karakter). Jakarta: Bumi Akasara.

Mirawati, 2011. “Peranan Keluarga Dalam Pendidikan Karakter Anak Usia Dini : Studi Deskriptif pada Keluarga di Perumahan Graha Bukit Raya II RW 24 Desa Cilame Kecamatan Ngamprah Kabupaten Bandung Barat “. (Tesis). Bandung: Perpustakaan Universitas Pendidikan Indonesia.

Munasir. 2011. "Model Pendidikan Akhlak Bagi Anak Dalam Keluarga Kyai: Studi Kasus Pada Tiga Keluarga Kyai di Desa Rancahilir Kec. Pamanukan Subang “. (Tesis). Bandung: Perpustakaan Universitas Pendidikan Indonesia.

Muslich, Masnur. 2011. Pendidikan Karakter Menjawab Tantangan Kritis Multidimensional. Jakarta: Bumi Aksara.

Mustari, Mohamad. 2014. Nilai Karakter Refleksi Untuk Pendidikan. Jakarta: PT Rajagrafindo Persada.
Naim, Ngainun. 2012. Character Building. Jogjakarta: AR. Ruzzmedia.

Ngurah, Ida Bagus. Dkk. 2007. Dharma Prawerti Bahan Ajar Pendidikan Budhi Pekerti Untuk Siswa SMA/K Kelas X. Denpasar: PT. Tri Agung.

Pudja, G. dan Rai Sudharta, Tjokorda. 2002. Manawa Dharmasastra atau Weda Smrti. Jakarta: CV.Felita Nursatama Lestari.

Shochib, Moh. 1998. Pola Asuh Orang Tua Dalam Membantu Anak Mengembangkan Disiplin Diri. Jakarta: Rineka Cipta.

Somvir. 2005. Niti Sataka (100 Sloka Tentang Etika dan Moralitas). Denpasar: PTEmpat Warna Komunikasi.

Sudharta, Tjok. 2003. Slokantara. Surabaya: Paramita.

Suhardi, Didik. 2014. Nilai Karakter Refleksi Untuk Pendidikan. Jakarta: PT Raja Grafindo Persada.

Supatra, I Nyoman Kanduk. 2005. Dana Punia Jalan Menuju Tuhan. Denpasar: Pustaka Bali Post.

Swastika, I Ketut Pasek. 2007. Suputra Bhakti Kepada Leluhur. Denpasar: CV Kayumas Agung.

Tampubolon. 2004. Penerapan dan Pendekatan Teori Sistem : Studi Kasus Universitas HKBP Nomensen. Sumatera Utara: Fakultas Teknik Universitas Sumatera Utara.

Titib, I Made. 1998. Veda Sabda Suci Pedoman Praktis Kehidupan. Surabaya: PT. Paramita.

Titib, I Made dan Sapariani, Ni Ketut. 2006. Keutamaan Manusia Dan Pendidikan Budhi Pekerti. Surabaya: Paramita.

Winardi. 1980. Pengantar Teori Sistem dan Analisa Sistem. Bandung: Karya Nusantara. 